\title{
The new European Jihadism and its avatars
}

\author{
Farhad Khosrokhavar
}

European Jihadism has evolved since it first appeared in the 1990s. In many European countries, at the outset, it tended to be restricted to the 'disaffected youth' from the poor suburbs (France) or poor inner city areas (in the UK), but it rapidly spread to the middle classes, whether Muslims or converts. In 2013, with the civil war in Syria, Jihadism underwent major changes. Before that it was restricted to a few hundred people, but it has now risen to several thousand (around 5000 young people have left Europe for Syria and their number would have been much higher had the governments not established controls preventing the departure of adolescents via Turkey to Syria). At the same time, adolescents have become numerous and the number of girls and converts has sharply increased. The aim of the article is to propose an understanding of the mindset of these new social actors in the light of the internal conditions of European societies.

Farhad Khosrokhavar is Professor at the Ecole des Hautes Etudes en Sciences Sociales in Paris, France. His main fields of study are the social movements in Iran, mainly after the Islamic Revolution; Arab societies, in particular radical Islamist movements therein; the Arab revolutions; Jihadism in Europe with a focus on France. His latest books are: Jihadist Ideology, The Anthropological Perspective, Aarhus University, Denmark, 2011; The New Arab Revolutions that Shook the World, 2012, Boulder, Colorado; Radicalisation, Paris, 2014; Le jihadisme, (with David Bénichou \& Philippe Migaux), Paris, 2015.

\section{Introduction}

European Jihadism, ${ }^{1}$ in the strict sense of the term, began in France in the 1980s. Between 1970 and 1980, France was the target of terrorist actions from the Middle East, mainly from Lebanon and Palestine, by the Abu Nidal groups, Carlos, or, at the beginning of the 1990s, associated with the Hezbollah. It was Iranian state terrorism (the assassination of Shapour Bakhtiar on 6 August 1991) which made a deep impression and had no deep roots in the French society. Until then, we had primarily witnessed acts of terrorism involving foreign actors or actors associated with conflicts, the outcome of which took place in France. Local grievances were marginal, or non-existent. It was mainly in relation to the Algerian military coup

1 By Jihadism, we mean a violent form of mobilisation in the name of a radical version of Islam which advocates the Jihad against the godless West and the Muslim countries which are also impious as a result of their Jahiliya, that is, their regression to a situation of idolatry, similar to the period preceding the Prophet of Islam. 
d'Etat against the Islamic Salvation Front (Front islamique du salut, FIS) that a wave of Jihadism hit France in 1995. We find individuals, sometimes from abroad or who had lived and grown up in Europe, but often of Muslim origin (and increasingly converts) who become radicalized and endeavour to perpetrate attacks to combat heresy and impiety (kufr), particularly in relation to the involvement of European countries in wars with Muslim countries (Bosnia, Afghanistan, Iraq, Syria, Mali), or again, to denounce the desecration of Islam (like the caricatures of the Prophet of Islam by journalists, first in Denmark and then in France by Charlie Hebdo). The series of major attacks which made a lasting impression began in America with the 9/11 attacks on 11 September 2001 in which almost 3,000 people died, then those in Madrid on 11 March 2004, with 191 dead and 1,858 wounded, those in London on 7 July 2005, with 52 killed in addition to the terrorists themselves and approximately 700 wounded, then those perpetrated in Toulouse and Montauban in 2012 by Mohamed Merah when 7 people died, Mehdi Nemmouche at the end of May 2014 in the Jewish Museum in Brussels in which 4 people were killed and the attacks in January 2015 when 17 people died. In Europe, following the civil war in Syria, as of 2013 a new form of Jihadism spread throughout most countries and its new actors had many new characteristics, were by far more diversified than before. The years 2013-2015 are a watershed in the history of Jihadism in Europe since the sheer number of terrorists increases manifolds (up to 5000 at the end of 2015), whereas in Europe they were in a much more reduced numbers until the establishment of ISIS (Islamic State of Iraq and Sham or Daesh, the Arabic acronym); new categories of terrorists appeared that were either non-existent before that period in Europe (the adolescents, boys and girls) or marginal in numbers (women and young girls who make up around 600 out of the 5000 migrant jihadists to Syria and Iraq, converts who constitute between 20 and $30 \%$ of the jihadists according to the countries...). The 13 November 2015 terrorist attacks in Paris that killed at least 130 and injured more than 413 people are a new case in which terrorists of Moroccan, Belgian and French origin conceived their plans in one European country (Belgium) and executed it in another (France), creating disarray in the ranks of the intelligence services in Europe whose cooperation is based on national interests rather than global, European stakes. The March 222016 attacks in Brussels underline as well the "Europeanization of Jihadism", the same cells having operated in November 2015 in Paris and March 2016 in Brussels. Foreign policies of the European governments play a role in the attacks against specific countries. For instance, in France, Khaled Kelkal attacked the Metro station in 1995 due to the assistance of the French government to the Algerian military that toppled the legal FIS (Front islamique du salut) government, dominated by the Islamists. In the same vein, Mohamed Merah killed Muslim military men in 2012 due to their involvement of the French government in Afghanistan and other Muslim societies. The November 132015 attacks in Paris were retaliation against the French aviation bombing Syria; the 2005 attacks against the London underground and bus were a 
response against the British involvement in the Iraq war initiated by the US. European Jews are killed by the Jihadist terrorists due to the Israeli repression of the Palestinians. But some attacks have no geo-strategic reasons: The attacks against the Charlie Hebdo journalists in January 2005 by the Kouachi brothers was due to the desecration of the Prophet Mohamed by that magazine and no foreign policy motive was put forward by them. Coulibaly, another jihadist who killed Jews in a supermarket close to Paris referred to Daesh for his attacks against them but the major reason was the caricatures of the Prophet by the magazine for the two major assailants, the brothers Kouachi. Globalization ${ }^{2}$ affects as well Jihadi terrorists who mingle with the others in Syria, Iraq, Mali, Yemen and Libya, although linguistic and cultural markers are still prevalent. Many European Jihadists learn to be "neo-Umma" (the imaginary Umma conceived by the Jihadists) followers once outside their countries of birth and become insensitive to the plight of their former fellow countrymen whom they characterize as "miscreants" and whose plight during the terrorist attacks in Europe becomes a minute damage in their eyes, compared to that of the Muslims suffering from the misdeeds of the Western governments. In Europe, ${ }^{3}$ terrorism in the name of Allah concerns only a minute fraction of Muslims but its social impact, disrupting society and creating a profound crisis at the level of the symbolic foundation of social order, is in no way related either to the effective number of its perpetrators, or to that of its victims.

\section{Several generations of European Jihadis}

Several generations of Islamist radicals, which can be identified in Europe, ${ }^{4}$ share the characteristic of being what the British call "homegrown" terrorists, meaning that they were brought up and educated in European countries. The first known case begins with the military coup d'état in Algeria in 1992. This put an end to the 1991 parliamentary elections in which the Islamic Salvation Front (FIS) obtained the majority vote. This Front gradually became a terrorist group, the Algerian Armed Islamic Group (GIA) and then formed several smaller Jihadi groups, which intended to punish France for its support of the army. The Sahrawi imam, from the moderate wing of the FIS was killed on 11 July 1995 in Paris. In the same year, a bomb planted in the Saint Michel/Notre-Dame station on line B in the RER Parisian underground killed 8 people and wounded 117. On 17 August another attack took place at the Etoile in Paris in which 17 people were wounded by a home-made bomb. Then there was a further unsuccessful attack on the highspeed Paris-Lyon railway on 26 August 1995. Khaled Kelkal, a young man of Algerian origin was involved in these attacks; along with others like Karim

2 Raflik 2016.

3 Neumann 2015.

4 Akbarzadeh 2010. 
Koussa, his friend, Boualem Bensaïd and a few other Jihadis, they committed attacks in France. Khaled Kelkal was killed in a confrontation with the police on 29 September 1995.

After him, and those in his orbit, we can list the case of the Roubaix Gang; most of the members had fought in Bosnia in 1994-95 during the war in Yugoslavia, alongside the Muslim militia. After the Dayton Accords in December 1995, which ended the war, the members of the group came back to France and organised hold-ups to finance the holy war.

Throughout 1996, the members of the group which comprised French converts, like Lionel Dumone and Christophe Caze and youths of North African origin including Ommar Zemmiri, Mouloud Bouguelane and Hocine Bendaoui carried out hold-ups in the area surrounding Roubaix and Lille. On 29 March 1996 the police moved in on their flat in Roubaix; four members of the group died in the fire which broke out, three others succeeded in escaping, one of them being killed in a confrontation with the Belgian police. The gang was thus disbanded.

Since then, there have been the attacks in Madrid in 2004 and in London in 2005; all the others have been neutralized by the police across Europe. It was not until 2012 that we witnessed successful attacks in France under the aegis of Mohammed Merah, a young Frenchman of Algerian origin. In March 2012, he killed 7 people and wounded 6 in Toulouse and Montauban. These included 3 soldiers, of whom 2 were Muslims, and 4 people who were Jewish.

Two years later, on 24 May 2014, Mehdi Nemmouche assassinated 4 people in the Jewish Museum in Brussels.

Less than one year later, the two brothers, Saïd and Chérif Kouachi killed 12 people in the attack on the weekly publication Charlie Hebdo on 7 January 2015, to punish the journalists for desecrating the Prophet of Islam in their caricatures. On 8 and 9 January of the same year, 5 people, a police woman and 4 Jewish people were killed by Amedy Coulibaly, who acted in liaison with the Kouachi brothers. He met the younger one, Chérif, in prison.

\section{The characteristics typical of home-grown Jihadis: young people from poorer suburbs to the middle classes}

What do these acts have in common? We could create a profile of the "homegrown Jihadi" on the basis of these attacks from 1995 to Charlie Hebdo in January $2015,{ }^{5}$ they are all young people who have been in trouble with the law, have a history of offending either for robbery or being involved in trafficking; they are on file for delinquency and the great majority have served prison sentences for various periods. With the exception of Kelkal, who seems to have had a fairly

5 One can extend this consideration to a more general terrorist mindset. See Post 2007; Horgan 2005. 
"normal" family, the others all had an unhappy childhood, often in residential institutions and a history of mental instability which has made of them people with problems from a very young age (this was also true for Zakarias Moussaoui, imprisoned for life in 2006 in the United States for his part in the 9/11 attacks in September 2001). Almost none of them were practising Muslims; they became "born again" Muslims, or Jihadi converts, under the influence of a guru, friends, or on the basis of texts read on the Internet ${ }^{6}$ or in prison. ${ }^{7}$ Lastly, by far the majority had made a journey of initiation to a country in the Middle East or to a war zone (Iraq, Syria, Afghanistan, Pakistan). Amedy Coulibaly was an exception; he was influenced by Djamel Beghal. For most of them, we witness a train of events starting with life in a deprived suburb or in a poor urban area in the UK, delinquency, prison, a journey to a war zone and radical Islamisation.

The majority of middle class youths found their vocation to Jihadism after the 13 November 2015 attacks in Paris. These young people, either of middle class or working class origin, are often second generation (as was the case for the majority of the perpetrators in the attacks on 13 November) but, among them, the sponsor from Daesh, was third generation. ${ }^{8}$

In the UK, one member of the group of doctors and engineers who attempted to commit a terrorist attack at Glasgow Airport on 30 June 2007, Kafeel Ahmed, was born in India and was therefore a first generation Jihadi; similarly in the United States, Tashfeen Malik, the wife of the Jihadi, Syed Rizwan Farook, was a first generation immigrant. There is therefore nothing specific about generation in this respect.

\section{The Jihadism of disaffected youths or the sanctification of hatred}

We can distinguish two types of Jihadis depending on the social class: those of middle class origin and those from the working classes, the majority being of immigrant origin along with some converts. In France, middle class youths who have participated in Jihadi attacks were a tiny minority before the 13 November 2015 attacks.

The mental universe of the disaffected youth, to use the British term, who embrace radical Islam is characterised by a hatred of society engendered by the ingrained feeling that they have of profound social injustice towards them. They experience exclusion as a heavy cross to bear, a stigma visible to all, with their accent, their language with its slang (verlan) and Anglo-Arabic expressions divested of their original meaning as well as their body language which is perceived

6 Lohlker (ed.) 2013.

7 Lohlker (ed.) 2012.

8 Vlierden 2015. 
as threatening by other citizens. They have broken their ties with society and reject the wearing of a uniform (even as a fireman) as an emanation of a repressive order. Their identity is defined in their antagonism to the society of the "integrated" whether they be French of Gallic or North African descent or British of Pakistani origin who have succeeded in rising to the rank of the middle classes. Stigmatized in the eyes of others, they are intensely aware of being subject to discrimination; this is conveyed by aggressive behaviour which is easily set off, not only towards other people but also, and frequently, towards members of their own family, in particular a young brother or sister who would dare to go out with a boy (they themselves go out with the sisters of their friends but double standards operate in relation to women). The suburb-ghetto becomes an internal prison and their self-hatred becomes hatred of others with their negative evaluation of others becoming a lack of self-esteem. Their main aim is to demonstrate their rebellion through negative actions, rather than by endeavouring to denounce racism by getting involved socially. However, by dint of hard work, some of their fellow brothers do succeed in overcoming exclusion and in entering the middle classes. But as a result they leave the poorer suburbs and often break their ties with their old friends. Relegated to their local area or even to a few blocks of houses, the excluded youths resort to delinquency and the search for easy money to live the kind of middle class life of their dreams, sometimes even going further when they get their hands on fairly large sums of money which they squander with their friends, even if this means going back to delinquency which gradually becomes criminal. The plight which most affects them is victimisation and the certainty that the only means of acceding to the amenities of the middle classes is delinquency; according to them, society has closed all the other entrances. As long as hatred finds an escape route in delinquency, it is allayed by access for short periods to material comfort followed by the dissipation of illegally acquired goods. But for a tiny minority, deviance alone does not suffice; they require a form of self-affirmation which combines several features: the restoration of their lost dignity and the desire to assert their superiority over others by putting an end to their lack of self-esteem. This is inherent to their innermost self as a result of their internalisation of the discrimination associated with living in poor housing estates, delinquency and a life which is unstructured and devoid of any mental stability. The mutation from hatred to Jihadism consecrates their anger and enables them to overcome their malaise by adhering to a vision, which makes of them a knight of the faith, with the others being infidels who do not deserve to live. The life change is thus complete; the Self becomes pure and the Other impure. Radical Islamism effects a magic reversal which transforms lack of self-esteem into lack of esteem for others and lack of respect into consecration of the self at the expense of others. Henceforth, feelings of worthlessness and of lack of vocation in a society in which the only means of survival were odd jobs and delinquency are ended. One becomes a real person and does everything to ensure that this realization that one seals by becoming a Jihadi, is recognized by others, in particular by the media. The 
media are inseparable from Jihadi action which only exists by combining violence with media coverage which makes a world star of the young knight of the faith due to his most dreadful action. The bigger the space the media devotes to him, even posthumously, the prouder he is of personifying the ultimate actions of a faith whose existence is due to the mutation of lack of self-esteem into hatred for others and the discrimination experienced into an ultimate form of sanctity. In so doing, an identity which has broken with others endeavours to take revenge for its misfortune on the society in question, which becomes guilty in its totality, with no exception, or, in Jihadi jargon, heretic or infidel: it has to be destroyed even if it means being killed as a martyr to the sacred cause.

In the Jihadi trajectory of youths from the deprived suburbs, prison plays an essential role, not so much for the process of radicalization as for the fundamental reason that it affords the opportunity to nurture a hatred of society in the everyday relationships infused with tension and rejection when faced with the wardens and, more globally speaking, the penitentiary institution. Each time prisoners break the internal regulations in prison, punishments remind them of the existence of a system whose legitimacy they challenge because of this intense feeling of injustice in the inner core of their being. Their fates are experienced as having been forged on a fundamental misunderstanding with society as a consequence of being only partly socialised. Prison does calm some, but most of the young people find therein more reason to hate society. In prison, they form relationships with hardened criminals who are likely to show them new perspectives on delinquency. Joining radical Islam often takes place in prison; in part a function of the boredom of being left to oneself in an institution which regards the Muslim differently to the Christian or the Jew. In prison the young delinquent experiences the lack of respect for Islam in an institutional and impersonal form: the lack of or scarcity of Imams, non-celebration of prayers on Friday, or worship in conditions where an atmosphere of suspicion surrounds the participants, such as the refusal of prayer mats in the recreation yard. Furthermore, the domination of the Salafists ${ }^{9}$ over the Muslims in prison acts as a premonitory form of introduction to the rationale of rupture with society. Usual Salafists are not Jihadis but advocate an exclusive version of Islam which contributes to de-socialising young people by introducing an unbridgeable divide between the believer and the non-believer, the true Muslim, who is assiduous in their religious practice and the counterfeit Muslim, who is laxist and has little respect for religious taboos.

9 There are at least two distinct groups whose members claim to be Salafists. The first, by far more numerous, encompassing more than ten thousand people in France are called "pietist" or "scientific" by the others: they are apolitical, promote da'wa (proselytism) rather than jihad. The second, called Salafist jihadist, is a minority and believes that violent action against the "idolatrous" governments (taqut) is the only way to save Islam. See Olidort 2015. 
One may begin by being attracted by radical Islamism; the harshness of prison, along with the amount of time one spends alone with nothing much to do, makes people susceptible to the call of the sirens of sacred violence. In prison, the attraction of radical Islamism is related to the reversal of roles, which is taking place in the troubled psyche of the youth. They have been judged and given a prison sentence; henceforth, it is the youths who condemn society in no uncertain manner, the youths take on the role of judge as knights of faith at war with the infidels. The reversal of roles restores the prisoner's self-confidence, and he now becomes a noble individual carrying out a divine command. As a result, hardened Islamists do not experience any remorse when confronted with the extent of their violence and the dehumanisation of their victims to whom they deny any dignity.

One last fact convinces the apprentice Jihadi of the legitimacy of the cause which they defend, the initiation journey to a Middle East country where the holy war is raging. Mérah had been in Pakistan, Afghanistan and other countries where radical Islamism was rampant; Nemmouche had been in Turkey and was strongly suspected of having lived in Syria for a year in 2012 alongside Jihadis; the two Kouachi brothers had been in Yemen where they had had military training with $\mathrm{Al}$ Qaida in the Arabian peninsula; Amedy Coulibaly may be the exception, even if there are traces of him having been in Turkey and possibly in Syria. In any event, he had met a charismatic Jihadi, Beghal, who put him in touch with Chérif Kouachi. In this case, the charismatic guru replaced the journey of initiation.

In most cases, the initiation journey confirmed the young Jihadi in their identity, by renewing links in a mythical manner with the Muslim societies, despite the fact that they neither speak the language nor do they share the habits. This journey enables them to learn how to handle weapons, but at the same time, it also enables them to become "foreigners" to their own society. In particular, they learn how to become "cruel", how to execute hostages or persons whom they consider guilty (members of the police, soldiers, Jews, "bad Muslims") professionally and without a qualm, in a word, to become a truly committed warrior of the hyperbolic Jihad who has absolutely no moral misgivings about killing the "guilty".

\section{The new middle class Jihadis}

In 2013, before the civil war in Syria it was exceptional to find middle class youths amongst the Jihadis. Since 2013, along with youths from rundown housing estates, they constitute a considerable proportion of the aspiring Jihadis who have flocked to Syria to offer their services either to the Islamic State (Daesh) or other Jihadi groups, such as the al Nusra Front (Jabhat al Nusra), which is Al Qaida in tendency. According to the statistics available, it is estimated that approximately 5,000 young Europeans have gone to Syria and numerous attempts to leave for these countries (especially via Turkey) have been neutralised after many European countries passed laws to prevent these departures. 
The regressive utopia of the neo-Umma, combined with the role of the white knight to the Jihad does have an undeniable fascination not only on some of the youths from the poorer suburbs but also, and for different reasons, on young middle class youths in search of a meaning, and they comprise the second group seduced by Jihadism since the civil war in Syria in 2013.

These middle class youths, often teenagers who are late developers (psychoanalysts consider adolescence lasts until the age of 20 or even 25 for late postadolescence), swell the ranks of the reserves of the Jihad by converting from almost any religion to radical Islam. Disenchanted Christians in search of the thrills which institutionalised Catholicism cannot provide, secular Jews tired of their Jewishness with no religious roots, Buddhists from French families who converted to Buddhism some time ago and who are seeking a revitalized identity in the service of the holy war in contrast with the pacifist version of this religion in Europe. There are also young women, often from good families, who have joined the horde of contenders for the ever-intensifying Jihad, to some extent in search of a post-feminist experience which they imagine will be somewhat exotic and give meaning to their rather boring lives.

In contrast to the youths from deprived areas, those of middle class origin are not motivated by hate for society; they have neither interiorised the exclusion which the former have encountered nor do they consider themselves to be victimised. They invoke humanitarian grounds to justify their opposition to the fascistlike Assad government and many of them are at a stage which could be described as "pre-Jihadist" ${ }^{10}$ before their departure for Syria or Iraq. Their problem is one of authority and norms. Authority has been weakened by the now irreversible evolution of the stepfamily, and the rights of the child have created a "pre-adult" who is frequently an over-age adolescent. The combination of an approach in terms of rights and the fragmentation of authority between the various parents and a society in which the norms have lost their stringency (including those of the republic) creates a crisis in authority which explains the attraction of an appeal to norms and a robust authority. A minority of these youths are even fascinated by them as they suffer from having several guardians but no single person in charge and would like the line between what is and what is not possible to be explicitly drawn. Islamist norms offer them this vision in black and white; what is forbidden is defined very clearly. Radical Islamism enables one to combine the pleasure of a game and the deadly gravity of the Jihadi faith. It gives a sense of conforming to intangible norms but also of being the agent who imposes these norms on the world, of reversing the role of the adolescent and the adult (the youth imposes them on frightened adults), of being the person who establishes the sacred norms and who imposes them on others under penalty of the holy war.

Fascinated by the Jihad, these young people are the personification of the antiMay 68 ideals: then, young people sought the intensification of pleasure in the

10 See Khosrokhavar 2014. 
infinity of sexual desire regained; nowadays the aim is to define the parameters of desire and, by means of a rigorous Islamism, impose restrictions on oneself thus raising one's self-esteem. In the past one endeavoured to free oneself from unwarranted restrictions and hierarchies, nowadays these are eagerly sought. There is a demand for sacred norms which are beyond human judgement and side with divine transcendence; these norms are aspired to and consecrated, carried along by the holy war.

In the past, we were anarchist and we abhorred patriarchal power; nowadays we live in a society devoid of meaning; radical Islamism, by separating the role of the woman and that of the man, rehabilitates a distorted version of patriarchy consecrated by reference to an inflexible and intransigent God, in contrast to a watered-down republicanism or an over-humanised Christianity. May 68 was a continual party and the hippie movement saw itself as its continuation in the excitement of the exotic journey to Kathmandu or to Afghanistan, which had not yet fallen under the sway of the Jihad. Now the journey of initiation is a quest for purity in the confrontation with death in the name of martyrdom.

Women's Liberation was an integral part of May 68. Now post-feminist young women assert their weariness with a feminism which has brought them formal equality which they have to assume along with the hazards of a freedom which is increasingly heavy to bear when confronted with a world which is still overwhelmingly masculine in its privileges and favours.

Alongside the fantasies of sacred standards, we also find the quest for justice for Syria where a bloodthirsty regime has killed more than 250,000 people according to various estimates, and has forced several million others to leave for neighbouring countries. These young people identify with a form of humanitarian aid which operates under the auspices of a so-called caring Jihadism. There where the West has demonstrated its impotence when confronted with a bloodthirsty dictatorship, these young people, armed with a naïve faith, intend to combat evil in the name of a form of religion whereas they do not grasp its monstrous and dehumanising aspects. The transition may take place gradually, as was the case for some members of the gang in Roubaix, such as Christophe Caze who participated in humanitarian aid in the 1990s and then became a radical Islamist.

Apart from the post-adolescents, the affiliation of young middle class adults to Jihadism in its version as exported to Syria poses the question of the malaise of these youths who suffer from the decline of the political system over and above their indignation at the lack of justice in a Syria which is rendered close by the media and where crimes against humanity of monstrous dimensions are committed. As far as the youths from the deprived suburbs are concerned, an infra or supra-political attitude has been the general norm. Self-absorption, withdrawal into the ghetto, or again, into violence in its sordid (criminal) or sacred (Jihadism) version are attitudes located either above or beyond the political. ${ }^{11}$ In the middle

See Wievorka 1988. 
classes, since the 1980s politics has been undergoing a major crisis and a whole generation has grown up with no political references whatsoever. For them, Jihadism is the consequence of the eclipse of the political as a collective project generating hope.

\section{The invention of the neo-Umma}

Radical Islam has invented a custom-made neo-Umma which has absolutely nothing to do with the historical tradition of the religion of Allah. Historically, appeals for Muslim solidarity have been made regionally or nationally to the Muslim community or Umma (and as of the $19^{\text {th }}$ century against Western colonialism). In the actual history of Muslim societies, the historical Umma has never included all Muslims and from an early date the Sunni / Shia division limited the scope. Radical Islamism has created a fantasy Muslim Community at planet level from scratch, which has no historical precedent. The neo-Umma is a utopia every bit as dangerous as a class-less society or one of the heavens on earth of the millenarians and, like all those hare-brained utopias, the danger it represents is the use of absolute violence in real life to implement it. In the neo-Umma, the evolution of Muslim societies is denied and the pure and simple return to the Age of the Salafs (Muhammed's companions and his disciples to the $3^{\text {rd }}$ generation of the Hegira) is advocated literally, legitimating practices such as slavery: the Yezidis in Iraq were enslaved or killed, their wives and daughters sold, the primitive forms of Talion Law (ghisas) brought back into force and summary judgements justified on the basis of the presumed transparency of Islamic jurisdiction. Young "Jihadists" have an overwhelming urge to be part of the neo-Umma as opposed to their own society which they dislike. To raise their self-esteem, Jihadist Islam offers them the status of absolute hero, clad with the prestige of martyrdom which, as a mujahid they personify (a fighter for the faith - the word having the same root as the jihad). They will kill, terrify, be hated and will be proud of the new status which they have acquired by virtue of occupying the front page in the media, overcoming anonymity and insignificance by the unhealthy fascination that they exert over the media. This propagates the image of the "anti-hero" which he values especially, as it evokes absolute fear in others. Henceforth, he is "someone" and he has succeeded in replacing the contempt with which "white" people regard him with the fear of death which paralyzes them. He is ready to die and to kill, the others fear for their lives, therefore he is their superior. In a way, he thinks they recognise this, by devoting the "front pages" of the media and whole issues exclusively to him. 


\section{Jihadism and the absence of political utopia}

Since the French Revolution, politics have played a major role in the way citizens define themselves. Politics have played several roles which have revolved around the socialisation of citizens, and their political and social advancement over time, the horizon being some point in the future. Even when poor, citizens could hope to improve their lot not only individually but by identifying with a universal cause, like the freeing of the proletariat from the yoke of capitalism or again, the implementation of republican equality through education and by State intervention. Politics also played a fundamental role in the subjectivity of citizens, that of their subjectivization and responsibility for their dignity. It was possible to be poor (an unskilled worker) but to be respected, identification with a cause shared by other workers enabling material conditions to be overcome in pursuit of an ideal society at some future point in time.

This civic construction has been shattered in the past few decades. Henceforth, the horizon of hope is not any nearer, contrary to the past, when all citizens could consider that the generation of their children would have a better social and economic situation than their own. At the moment, young people, even those of the middle classes, are beset by the fear of downward social mobility. As for those of working class origin, for the great majority of them the improvement of their situations by legal means seems to them unrealistic. To put it briefly, the prospect of social mobility is almost non-existent for almost everyone. Both the young middle class person who fears downward social mobility and a youth from the deprived suburbs who has no faith in advancing his or her cause in the future, share a lack of future prospects. Jihadism reconstructs this lack of prospects on false premises but which young people do not take into consideration, in their desperate search for a utopia which gives a meaning to their lives by means of the sacred (the meta-political) and by the promise of perspectives for (infra-political) social promotion. In both cases, the new utopia is both exaggerated (the metapolitical) and minimised (infra-political) and the consequence is a political vision which is hyper-repressive and hyper-regressive, but which young people do not realise.

Young people in Europe, where politics is at a standstill and no global project for society is visible, are susceptible to mythical forms of politicisation where promises of happiness on earth, in the name of a fantasy neo-Umma and a heroic vision as a fighter for the faith confer meaning on lives totally devoid of any hope in the future. 


\section{The decline of the social utopias}

The attacks on 13 November 2015 revealed the extent of the malaise and the identification of a number of young people not only from the lower but also from the middle classes with a repressive ideology which is now replacing social utopias such as republicanism and communism. Since the 1990s the crisis in inherently utopian ideologies has led to the attraction of radical Islam as a "transcendent" utopia, which fills the ideological vacuum of modern societies. France, as it happens, is experiencing a deeper form of malaise because the basis of social life after the Revolution in 1789 has been political. The citizen is defined primarily by his or her commitment to the political pact establishing the Nation-State as the representative of the citizens, politics being simultaneously a principle of commitment to a republican project and the identification of the citizen with a principle of meaning which would enable the implementation of the ideals of liberty, equality and fraternity at some future point in time. The crisis in equality and fraternity means that equality of citizenship as a project for the future is impossible, particularly for the excluded. Any hope for the future in politics is now over; the last example was the movement for equality in 1986, which was a totally secular movement. The result is that radical Islam has now replaced the citizenship project. Henceforth for the adepts of Jihadism, equality is achieved in death and not in life, fraternity in the killing of the enemy and liberty in the desire to inflict death as the representative of God, a merciless God, unrecognisable in the Islamic tradition - a pure invention of those who see in belief only a justification for killing instead of the promise of a happy life in a world where people live in peace. Jihadism acts as a substitute for the extreme left ideologies like Action directe in France, the Red Brigades in Italy or the Baader-Meinhoff group in Germany. What remains of these leftist groups carries over into Jihadism some of the beliefs of this tendency, if only because of the "anti-imperialism" of radical Islamism which is opposed to the American, and to a large extent the European, hegemony in the Muslim, but also in the Western world.

\section{Jihadism and hyper-secular societies}

In the middle classes, the appeal of Jihadism must be understood as being due both to the attraction of a dream world that the Islamic State (Daesh) presents to young people ${ }^{12}$ and the vacuum they face in their daily lives from which any "sacred meaning" is banned in a more or less unconscious manner. It is not surprising that the few young Jewish Jihadis who have been recruited come from secularised Jewish families, the same observation being true for Catholics and Protestants, while many come from secular, non-religious families. A large pro-

12 Some scholars believe that ISIS (or Daesh) is a revolution. See Atran 2016. 
portion of young people do not endorse the hyper-secularization which reigns in society. This is imposed as something obvious by the family and the general attitude of society and a minority among new generations feel this more as a liability than an asset. Desacralization at global level, that is, the decline in Christianity and, more globally, the loss of meaning of the institutionalised religions renders the imagination inclined to seek in the unknown of new hieratical worlds a meaningfulness which is not provided elsewhere to those young people who suffer from the absence of an institutionalised reference to the sacred. For a minority of aspiring young people the "dis-institutionalisation" of Christianity in France, and in Europe more generally, frees religion from the shackles of traditions but for others this leads to a quest for meaningfulness in sectarianism in all its forms. For some, this is a form of emancipation, but for others it is a source of anguish given the absence of markers with respect to the sacred. The quest for a Jihadist Islam combines several registers inherent to the exotic aspects of a faith which provides a strong sense of the sacred and whose very intransigence breaks with the weakening of the Hieros/Sacred in present-day society. Furthermore, the many splits in step-families encourage the search for meaning concordant with a repressive Sacred, where absence of authority mutates into an inflexible authoritarianism within radical Islam, which is then desired for its extreme, repressive character. Everything seems to indicate that a proportion of young people from the middle classes combine the search for adventure, revolutionary romanticism, the desire to experience a form of "otherness" (the Sacred) and the desire to prove oneself by submitting willingly to a repressive form of interpretation of meaning. In European societies in which hyper-secularisation is synonymous with the denial of any transcendence, the Sacred is returning in the form of an oppressive configuration. This is both the result of a desire to prove oneself by contact with the Other (the experience of something radically different) and of embracing happiness in contrast with the gloom of a society in which a large proportion of young people suffer from the fear of downward social mobility, of proletarianization. The aspiration to Jihadism is in reality a quest for meaning through the "Jihadisation" of one's relation to the world, subscription to a form of repressive transcendence, infatuation with a type of religious experience diametrically opposed to the dominant "a-religiousness" which is the outcome of hyper-secularisation.

Until 1968, liberation consisted of getting rid of the traces of any unwarranted transcendence: patriarchy, the institutional forms of the Christian religion (particularly Catholicism), the refusal of hierarchy, the desire to satisfy one's sexuality outside the framework imposed by tradition and the quest for meaning through individualisation and the search for personal happiness. Nowadays, not much remains of the hierarchical forms of yesteryear to be challenged or demolished. These are being replaced by a new form of anxiety which is one of solitude in a world in which the decline of meaning is experienced at all levels of existence, both at the level of the workplace (no strong collective organisation at trade- 
union level) and at political level (no party which represents the sacred, as did the erstwhile Communist Party or the Republicanism which combined liberty and equality through fraternity). Political citizenship which governed the relationship to the sacred and in one way meant resort to religion was strictly private is no longer operational, the appeal to a "public religion" in the guise of radicalised Islam becomes very attractive in the eyes of a number of young people who regret the absence of any meaningfulness.

\section{Female martyrdom or regressive post-Feminism}

In Europe, and particularly in France since the civil war in Syria in 2012, we are witnessing the emergence of a female Jihadi, the novelty of which resides in particular in the appreciable increase in their numbers (previously, female Jihadis were the exception; at the moment we find several hundred European women in Syria and others who wanted to go there but were prevented from doing so by the authorities).

Another characteristic of these young women is that there are a good many adolescents or post-adolescents alongside other women in their twenties or thirties. These adolescents or post-adolescents are often in a dream world which is not a result of Jihadism, but at best of pre-Jihadism, projecting fantasies onto their involvement which, strictly speaking, have little relation to the reality of the ideological and mental world of radicalisation.

A third characteristic is that the majority are of middle-class origin and not working-class or from a poorer suburb.

A fourth specific feature is that a great many of them are converts: from Christianity, Judaism (a few cases), or even Buddhism or agnostic or atheist families.

Being of middle class origin, just like the men from the same social class, ${ }^{13}$ the main motivation for their departure to the war zones in Syria is not hatred of society. Several approaches interact, triggering their departure. In the first instance, a distorted vision of humanitarian action: their brothers in religion (Sunnites) need help, confronted as they are with the heretic and evil power of Assad (an Alawite, considered a deviant sect by the Sunnites) and one should take up arms to be alongside the men. The image of the idealised man is also the focal point of these young women who are often post-adolescent and disappointed with the feminism of their mothers or grandmothers. There is almost an idealisation of the masculine virility of those who expose themselves to death and who, in this confrontation, demonstrate their virility, their seriousness and their sincerity. These three adjectives give meaning to the "ideal husband". Additionally, he is apparently "serious". By fighting the enemy, he reveals a permanent commitment

13 See Thomson 2014; Bouzar 2014. 
unlike these young men, whose behaviour reveals aspects of immaturity and volatility in the eyes of these girls who seem to have deposed the image of the Father. They are seeking a form of masculinity in the superlative, coupled with the gravity of imperturbability in the face of death. These young men, prepared for martyrdom, personify the cliché of the ideal man. Finally, the third characteristic of these youths is their sincerity: since they accept to die for their ideal, they are likely to be "sincere" with their wives, their degree of reliability being evaluated in terms of their capacity to demonstrate their authenticity on the battle field. This type of young man, personifying the cardinal virtues of truthfulness, is apparently the ideal type of man to marry to avoid the malaise of the instability and everincreasing fragility which characterises modern couples. They are often children from step-families in France, having experienced the vulnerability of their parents' conjugal liaisons and the loss of masculinity in divorce proceedings. They reject both the image of the man and of the woman as it appears in modern society. They are seeking a form of utopia, in the anthropological sense in which the feeling of confidence and absolute sincerity would be combined with that of "acceptable inequality". The Jihadi sites in the Islamist State (Daesh) who know how to manipulate the feelings of these young women and exploit this type of fascination by speaking of the noble image of the woman, who is apparently sheltered from modern instability and has absolute confidence in the man who is apparently a major support (he is a "hero") and an unwavering tower of strength (he is in no way effeminate, he knows how to fight and meet the challenge of adversity). Above all, a naively romantic vision of love is combined with the attraction of war, or even of violence. Some of these young women are apparently fascinated by the violence of war. ${ }^{14}$ Furthermore, the first waves of these young women who have gone to Syria serve as "recruiters"; they send e-mails, write blogs, give an idealised image of the situation of the wife of the "mujahid" (a soldier in the Jihad) in Syria. Sometimes, once they arrive, the "muhajirat" (the immigrant women) marry Europeans who have joined the ranks of the Jihadi fighters in Syria, like Khadijah Dare, from London, who married a Swede fighting alongside Islamic State and who chose the name of Abu Bakr. ${ }^{15}$ In some cases, the violence of war fascinates not only the men, but also the young women. Life in this "special" situation assumes a meaning and an intensity which means they momentarily forget the inferior situation of the woman which is concealed behind the concept of "complementarity". The cultural rapprochement between men and women in Western societies also means that violence is not perceived as it was in the past as being the exclusive resort of the man, as the woman can also participate therein indirectly, at least by exercising it against other women perceived as being heretics (for example, the Yezidi women or the Assyrians enslaved by the Islamic

\section{Hoyle / Bradford / Frenett 2015.}

15 See article: "UK female jihadists run ISIS sex-slave brothels", in: Al Arabia News, 12 September 2014. 
State, being used to satisfy the sexual desires of the fighters; the running of these Islamist brothels is entrusted to young Western women who have converted to Islam. They are members of Al Khansaa, a police force which imposes Sharia Law on women).

Sometimes the whole family has emigrated to Syria and, as a result, mothers and daughters meet in this brigade, or in other cases, sisters who left together (the case of the 16 years old twins, Salma and Zahra Halane, who have joined this brigade). By taking some of these young girls into the brigades for the enforcement of their version of the Sharia, the protagonists of the Islamic State invest them with a form of legitimacy and in particular, confer on them power over the non-Muslims or the "bad Muslims", who are often older than them. This repression gives them a feeling of having become adults through the rite of passage of the assertion of their authority over other women. These same authorities encourage these young girls to marry combatants, preferably Europeans. Adolescent girls are declared fit (even from the age of 9 years, but this does not apply to the situation of young women who leave for Syria) to marry and to start a family in which the children will be indoctrinated by the Islamic State. Their excitement at the idea of starting an "Islamic" family of which they vaunt the social standing and in which they would fulfil the idealised role of the mother in the Caliphate, means that they do not realise that their importance is an illusion and their status of woman is inferior, something they refuse to see for the time being. These young girls have often experienced the instability of modern marriage or feel exposed thereto in their generation. As a result, a union for "eternity" with a champion of the faith satisfies their quest for a romantically indestructible bond of religiously legitimate love. This would enable them to escape the sinful friendships between young boys and girls in the monotonous world of a West devoid of widespread violence. The war-like atmosphere, the myth of Islamic purity under Daesh, the idea of the heroism of their man and their dignity as future mothers, and finally this world where violence becomes an entertainment which is so totally different from their own country of origin fascinates them for a while.

\section{Masculine virility, power, authority and the identity crisis}

The modern middle class family tends increasingly to be a reconstituted stepfamily. There are two fathers (the biological father and the "legal" father) and two mothers (the biological mother and less frequently, when the child lives with his or her father, the "legal" mother who is the wife of the father) which creates a space in which the child can benefit from more room for manoeuvre than in the past, by manipulating the authority of each member of the couple. The multiplication of sources of authority weakens it and at the moment, unlike the traditional patriarchal family, in which the child suffered from too much paternal authority, the rise in sources means the child can play one against the other and exercising 
authority becomes a source of stress and uncertainty for the parents. Furthermore, the rights of the child as a "pre-adult" means that the child becomes aware of certain rights earlier than in the past. The requirements of life and the length of studies mean that children may stay with their parents thus extending adolescence and its affective and economic dependence much later than in the past. This area for manoeuvre is also an area of stress: the dispersion or even absence of authority, the dizziness experienced when the young pre-adult is confronted with the space for manoeuvre available and which, via the use of internet, enables immersion in worlds other than that of the parents, where he or she can live a virtual existence, seems to them to be terribly real given the lack of solid anchoring of authority in their symbolic world. The result is that Jihadism plays on both these registers, by the use of the Internet but also by giving young adolescents the impression that they can become adults by embracing the cause of radical Islam.

On one hand there is a crisis in parental authority, on the other the diversification of imaginary worlds in which the virtual and the real tend to become indistinguishable through the interposition of social networks; finally in addition, a daily reality for girls is the impression of being surrounded by immature young boys who have lost their "virility" and have relinquished their masculine superiority of intelligence and know-how. Girls can now confront them in these areas on an almost equal footing. The demoting of young men is concurrent with the glorification of the young Jihadi whom the girls try to marry. What makes him so irresistible? The answer is loud and clear: confrontation with death. This is the touchstone of four fundamental features which are to some extent the portrait of the ideal man for these young girls: serious, sincerity, virility, stability and confidence. Contrary to the young boys whom they frequent and who no longer appear "serious", the Jihadis are "deadly serious". They are in a fight to the death with the enemy, they personify the "reality" of life and not this effeminate attitude of young men who take life lightly; they are also a "pillar of support" on whom young women can learn to bear the burden of an increasingly heavy life. The woman of the future must not only earn her own living, but also be responsible for the home. She must live with a man who is far from appearing perfect, having lost his symbolic status in personal relationships, in the first instance in the family where the erstwhile patriarchal authority has collapsed or the non-differentiation of male and female roles has resulted in a distressing lack of symbolic content, or even a de-sublimation of both the father and the mother. The man who confronts death reconnects with masculine values; he gives content to "virility", the revival of archaic relations and the masculine ideal which can only survive at the cost of confronting death, not life. It is as if everyday life engenders considerable anxiety which can only be surmounted by the idealisation of this new male, who fills the mental void in which one struggles for lack of any legitimate source of authority. The young woman considers that she can lean on this new man, a superman whose violence raises him above the crowd and creates meaning. We are reminded of these young women who write love letters to convicted criminals in prison, of- 
fering them their bodies and souls, even to those who, like Guy Georges (a serial killer and rapist of several women who got letters from young women wishing to be his lover for a long time), have committed dreadful sexual crimes, or Antonio Ferrara (one of the protagonists of organized crime) who got love letters from young women who admired his "outstanding qualities" and his exceptional masculinity. Sincerity is apparently the dominant feature of these fighters for the faith and young girls could entrust them with their destinies, with no fear of disappointment, given their distance from the peaceful (and by definition down to earth) life that these women live. A naïve romanticism combined with a quest for the exotic, as a change from everyday reality, characterises these young women in search of the absolute in the guise of a man who would satisfy their need for the ideal man, constantly disappointed by the "immature" young men whom they meet in their social circles.

The quest for authority at any price means that power in its most repressive form is eagerly sought. The aim is not only to "subject oneself willingly" to the repressive power (Daesh becomes the personification of this type of legitimacy), but to seek to do so fervently; the greater the repression, the greater the attraction. Consequently, there ensues a desperate search for "repressive transcendence" to guard against the absence of meaning in this widespread immanence in which we live, and where the new configuration of the family, the political and social order prioritises egalitarianism. But this form of the sacred is fragile and open to a number of weaknesses which means it is easily desacralized. In a hypersecular society in which nothing seems to be a matter for the sacred any longer, the only form of sacrality which resists this demotion is repressive in nature, like an archaic form of meaning to counter the absence of meaning in social relations which are no longer in any way sacred and have even become profane.

Why then is Islam the preferred choice in this quest for meaning? First and foremost, because of the vacuum in violent extremism on the ideology market: Action directe, the Red Brigades, the Baader-Meinhoff group all belong to the past. The extreme right is a source of inspiration to some but does not convey an ideology of sacrality. At the most, it presents a vision of democracy as no longer sacred, identifying the immigrant as the enemy to be overcome. Islam in its Jihadi version meets two contradictory requirements of the new European middle-class youth: on one hand, its vision is inherently anti-imperialist and on the other, hyper-patriarchal. Those who wish to fight the new world order dominated by the United States find ideological resources therein, and those who suffer from an identity crisis and have a need for an absolute transcendence find therein an inexhaustible source of repressive sanctification. Young men with a castration complex as a result of women entering all spheres of society can join (they are promised the restoration of a "patriarchy of heroes" which is attributed to divine will). Young women who complain of their disappointment with post-feminism in which they have to earn their living and deal with domestic issues are ensured of a new life in which they will be the "complements" of men. They will have the noble 
role of looking after the family without having to worry about the financial aspects which are ensured by men. Above all, they will be re-enchanted by the new role attributed to them of being the mother of future Jihadis. The nobility of these young men will rebound on them and their new social role; will in the future satisfy their desire for an undeniable exoticism. With this mental attitude, the fact that a young girl is leaving for Syria can serve as an encouragement for her friends to follow her, competition within the group and the group dynamics of the desire to do like everyone else becoming important factors. ${ }^{16}$

The young women who leave may or may not be of Muslim origin. Even when they do come from a Muslim family, most of the parents do not see the change in attitude of the young woman and remain in their own world in which communication with their children continues unaware of these new motivations. This ignorance is an indication on one hand of the widening gap between the two worlds, that of the adolescent and that of the adult, and on the other, the weakening of the concept of authority which, formerly, served to instil in young people normative forms of behaviour, independently of their own vision of the world. At the moment, the weakening of patriarchal authority and its exercise by several persons, along with the non-internalisation of imposed models of behaviour, creates a distancing effect. This may go as far as a total break with the family in the name of an ideal which the young person chooses either on social networks or in their complicity with friends of both sexes, without their parents' knowledge. They often suspect nothing. Take the case of the 14 year old Muslim girl who lived in Argenteuil, in the Val d'Oise; she left home on a Wednesday and sent a text message to her parents at $6 \mathrm{pm}$, asking them to look under her mattress in her room for the letter she had put there. She explained that she was leaving for Syria to be able to be free to follow her religion. ${ }^{17}$

\section{The situation of adult women}

We also find middle class adult women and women from the poorer suburbs who have left for Syria. In some cases, whole families, including the mother, have left France for Syria. In other cases, women have chosen Jihadism, denoting a considerable autonomy in relation to their spouse. In this respect, Hayat Boumedienne, 26 years old, born into an Algerian family of 7 children, is paradigmatic. Her mother died when she was 6 years old. She and some of her brothers and sisters were taken into care. She became a cashier; in 2009 she met Coulibaly and left her job, because she wanted to wear a full face veil. She left for Turkey on 2 January 2015, a few days before Coulibaly started his fatal attacks and left Turkey for Syria not long before the attacks. This means we can presume that she knew

16 See McVeigh 2014.

17 See article: "Une adolescente de 14 ans partie en Syrie", in: Le Figaro, 19 juin 2014. 
about Coulibaly's decision and his desire to die as a martyr in confronting the police. She apparently chose her own way, being pregnant and intending to join Daesh to bring up her child and live her own adventure as a Jihadi woman. Her vision of the world is totally different from that of the young middle class women and their hare-brained romanticism, due to being raised in an institution as a product of poverty and being Coulibaly's partner. She shares the world view of her "husband" who hated society and whose Islamisation was primarily the consecration of this hatred. Her proactive approach (she chose a different way from her husband) expressed a type of autonomy on the part of some Jihadi women, who share the ideals of their husband but opt for a different way (departure to Syria), rather than remaining by their side. Her example, like that of many young women who have gone to Syria, demonstrates that the customary interpretation which designates them as "victims" of fundamentalism or of the Arab-Muslim patriarchy is clearly defective. They take initiatives, behave as true protagonists of the holy war and assert this attitude quite unambiguously. Jihadism reveals, at least among young adult women, an undeniable capacity for individualisation, even if their self-assertion will end in their being relegated to a situation of insurmountable inferiority, once they have accepted to live under the aegis of the Islamic State of Syria and Iraq.

Alongside these young girls and women who opt for Jihadism, harbouring the illusion of recognition, whereas it is inferiority which awaits them, we find the diametrically opposite example amongst the Kurds. The women Peshmergas have taken up arms against Daesh and have succeeded in gaining recognition in a status - even if still ill-assured - of equality with men, creating a breach in the male privilege of handling deadly weapons in the struggle against the enemy. ${ }^{18}$

Twenty-six year old Hasna Ait Boulahcen, a woman of Moroccan lower middle class immigrant origin, is another example. At the age of 8 , she was placed in a children's home and developed mental difficulties as a result of the break-up of her family home. She could not settle in a foster family and often ran away. Whereas the Boumedienne case is that of a young woman who knows what she wants and becomes involved in the Jihadi venture to assert her autonomy with respect to her partner, Amedy Koulibaly, Hasna gives the impression of a young woman who is lost and who joins in a spirit of adventure to assert herself in forms of radicalisation, which are frequently simulated. She finds herself implicated in terrorism when her cousin, Abdelhamid Abaoud, asks if he can stay with her after the 13 November attacks. The Jihadism of young adult women seems to waver between these two models of self-assertion (Boumedienne) and an identity which hesitates between indecision and pretence at Jihadism (Boulahcen).

18 Darmency / Desloire 2014; Salih 2014. 


\section{Jihadi propaganda and its impact}

The Al Qaida form of Jihadism was built on the membership of young people and propaganda for the West by means of electronic journals, such as Inspire hosted by Anwar al Awlaki, an American of Yemenite origin, who was killed by American drones in September 2011. There were also supporters and resources from the internet. But this was all rather amateurish compared with the new Islamic State, Daesh, which had specialised services to attract young people from all over the world. It is estimated that between ten and twenty thousand foreigners have gone to Syria in support of the Jihadis; of these, between two and four thousand are Europeans and this includes a few hundred women and young girls. Every effort is made to attract men and women to take up the struggle against the opponents of this new State. In the videos for young women on YouTube, there is the glorification of a different form of femininity, the insistence on their religious duty and their capacity to have a stable and pure family in which the sincerity of the combatants for the Faith would give meaning to their lives. Other strategies, dependent on age and social origin have also been used; for example that participation in the Jihad would put an end to depression (sic!) and that the Holy War would be a cure against this chronic mental illness in the West, the latter message being aimed at men but being equally applicable to women. ${ }^{19}$ Young women, sometimes referred to as "Caliphettes" in reference to the Caliphate set up by Daesh exhort young girls and women on social networks to come and join them to defend Islam and marry one of the "fighters for the Faith" ${ }^{20}$ The propaganda instituted by Daesh via the Internet is now much more widespread and professional than under Al Qaida; it encourages young women to leave their families and join the hordes of Jihadis in Syria. By appealing to them directly, Daesh primarily gives adolescents the impression of being fully fledged adults and of being recognised as such, capable of founding a family but also of having children, attributes which in the West are reserved for adults and which, cleverly manipulated, gives them the impression of being taken seriously by this new Islamic state even if they are treated as under age at home. The euphoria of being grown up before 18 masks the inferiority which this will induce; women are confined to a role of producing progeny and managing the household in a division of labour in which they would find themselves confined to the private sphere. The manipulation, which is cleverly orchestrated, consists of giving them the illusion of being adults as of a right whereas they are not. Fascination with adulthood before the legal age and the privilege of participating in the adult world in the land of Islam, proves to be a powerful motive for a hasty departure, unknown to their parents who are now perceived as a hindrance in the access to this state of enjoyment of full rights which they so desire. The illusion of so doing before the legal age

\footnotetext{
19 Siddique 2014.

20 Halicek / Pandith 2015.
} 
exhilarates young girls in search of recognition, and their impatience to be independent.

Overall, the highly developed, if not sophisticated, nature of Jihadi propaganda consists not so much in stressing the ideology, as the emotions and the impression of well-being, inspiring in men warrior virtues and in women the cult of masculine virility in the confrontation with death. In a word, the female version of Jihadism was very exceptional before the civil war in Syria. European women as Jihadis were extremely rare and amongst them one can find converts (Muriel Degauque) as well as immigrant-origin Muslim women. With the departure to Syria, we witness the flow of women and young middle class adolescent or post-adolescent girls to Syria. This new phenomenon has cultural origins in the break-up of the traditional family, but also social origins and in particular the effect of imitation within the group and the desire for self-assertion, in particular in the choice of a man with exceptional qualities, capable of sacrificing his life for his ideal. In short, this is a man who personifies the status of hero. It is also the outcome of the rapprochement of attitudes of young men and women after several decades of feminist culture in the West.

Jihadism which, in France, was primarily a phenomenon fostered by life in deprived suburbs (with rare middle class instances) is thus extending to middle class youths, the girls becoming distinctly more numerous than in the past. In the middle classes, the dichotomy between men and women does not exist to the same extent as in the poorer suburbs, and the behaviour of men and women is increasingly homogeneous in practice. What attracts men has a quantifiable effect on women despite the psychological differences which separate them.

Furthermore, there is a major difference between the propaganda of Daesh and that of Al Qaida. Daesh "individualises" the martyr and the Jihad warrior, giving him a specific face in his video sequences and does not particularly insist on the religious dimension of their involvement, but on the exceptional nature of their action as well as on their heroism and their romanticism. For example, we see fighters for the faith in tears, and openly manifesting their emotions which has no equivalent in Al Qaïda. Whereas Al Qaïda advocates a degree of revolutionary asceticism, Daesh, for example, shows young fighters bathing in a river, thus exalting a sense of "Jihadi tourism" which is not found in Al Qaïda. Al Qaïda highlights the celibacy of the fighters, while Daesh endeavours to marry them with one another so that they constitute a family in the Islamic State. The advertising in "Islamic State" gives very little space to religion, exalting the impression of warlike virility and of exceptional heroism amongst these young adepts rather than references to Islam strictly speaking.

On the whole, the Jihadi propaganda targeting young Europeans is done by Europeans in the pay of Daesh and this is why the accent is on what will attract them and draw them to Syria. 


\section{Death as a guideline in Jihadism}

Jihadism in Europe entered a new phase with the civil war raging in Syria. Almost every country in Europe has sent its contingent of Jihadis to this country and their overall number is estimated to be several thousand. There are also those from countries like Tunisia (roughly 3,000 Jihadis) and Pakistan (several hundred) where there are people who may have direct links with France (Tunisia) and in the UK (Pakistan).

This phenomenon shows the interlinking of a transnational problem (the war in Syria) with social and cultural problems in European countries. The transnationalisation of economics and politics leads to transnationalisation of the imagined Umma (the "neo-Umma") and, above all, the possibility of mobilisation of young people, both women and men, in the West (including America but to a lesser degree) towards achieving its goals as promoted in the Daesh propaganda. Jihadism shows the increasingly globalised dimension of this neo-Umma and of the subjectivity inclined towards it, particularly amongst the new generations. The quest for a new utopia and the feeling of profound injustice combines with the search for individual happiness and adventure in Jihadism, which reaches almost all strata of society. Paradoxical as it may seem in this situation, what unites the three categories of young people (young men from the poorer suburbs and from the middle classes and the young girls and women) is death. Death becomes the guideline of their troubled psyche. For young people from the deprived suburbs who are excluded socially and have internalised this exclusion as a form of radicalism, death becomes a fundamental category which makes them feel "invulnerable" as compared to people who feel lost when confronted with death. This is the foundation of their "superiority" over frightened opponents, who do not know how to deal with the agonies of death, for lack of a strong attachment to the Absolute. There is a taste for revenge in this capacity to overcome death which is based on the desire to disparage life in this world, with its lack of respect and selfrejection by internalising the afore-mentioned lack of respect. The saving death or martyrdom is a delivery in two respects: the first is the break with a society in which one has never felt at ease, given the extent to which one has been a prey to malaise and rejection by others; the second is that the other world is the scene of happiness for the martyr who will be in heaven, all their desires fulfilled, eternal joy being his rewards for his courage and his desire to impose the will of God by the sword.

From this perspective, death is the only point where fates are sealed and unsealed; a destiny founded on the rejection by others in turn becomes rejection of others. This two-fold dialectic is combined in a "desire for death" which reverses the vector of life by associating the desire to die with the desire to kill the other, the opponent, the world surrounding the young rebel. Henceforth he or she lives 
to espouse the fate of the negative hero ${ }^{21}$ by killing others. This type of hero achieves his goals by being totally rejected by the others, his goals making him a feared and detested person who achieves fame through notoriety. He kills, as Mohamed Merah did, Muslim soldiers who are the sworn enemies of Islam, but also Jews, these representatives of Israeli "arrogance" and "contempt" for Muslims in general in the Middle East.

For young middle class Jihadis, death is declined in another mode. It is not so much hatred of the other but a game with death which presides over their experience of martyrdom. They make light of life in the confrontation with death on the battlefield in Syria to overcome the virtuality of a life, which is spent primarily in a process of loss of prestige and self-esteem. Men are aligned with women in a unisex culture in which differences are masked and similarities exaggerated (the same clothes, the same dishevelled look, the same forms of kindness with no hint of the virility of the past). The very meaning of the sacred in a hyper-secular society, where there is almost no space for the religious, is disappearing. The virtual and the real world are aligned in these video games where the frontier between the two tends to fade. Finally life and death are aligned in an extended adolescence where the impression of invulnerability is now combined with the spectacle of others being killed and, in extremis, almost inadvertently, even oneself, on the battlefield where one can die or kill as if by magic in an atmosphere of amusement which recalls that of the games on the Web.

Finally, for the young women and girls who go to Syria to be enlisted by the Islamic State (Daesh), death is the sign of their adherence to the seriousness of a male world, a way of trusting men who brave death, but also a way of exposing themselves to death in turn, by virtue of this "unisex" culture which tends to be increasingly preponderant in the lives of young people where girls and boys have never had such an extensive cultural proximity. In this case, death becomes the link between the three groups, the young men, those from the deprived suburbs, those from the middle classes but also the young girls, mainly of middle class origin, who are going to join the heroes symbolically rubbing shoulders with their heroism (not so frequently in reality), basking in part of their glory while managing their sexual and family lives.

\section{The increasing importance of siblings}

In order to counteract the penetration of the security branch of the police force into the workings of their action, Jihadists increasingly choose family ties which bond the loyalty of brothers, or even other members of the family in the service of violent action. Merah benefited from at least the complicity of his brother (2012 attacks), without him being directly involved in the attacks; the Kouachi brothers

21 See Khosrokhavar 2014; Khosrokhavar 2015a; Khosrokhavar 2015 b. 
(2015 Charlie Hebdo attacks) cooperated directly in the killings, the Abdeslam brothers (13 November 2015, Bataclan attacks) demonstrate how family ties can be exploited to ensure that the group is not infiltrated by the security branch of the police; religious radicalisation also creates a bond which cements ties, which have been significantly eroded by delinquency and the break-up of families.

Furthermore, the sight of a close-knit family involved in a joint project symbolically reconstitutes the united family of the past, before the break up of families like those of Merah or Kouachi. In this reconstituted family, it is not egalitarianism, but the hierarchy of younger/older which reigns even if in real life, the symbolic elder brother is the younger in terms of age (this was the case of the Kouachi brothers where the younger brother made the decisions and the elder one followed). Finally, crossing swords with a society which one hates is a shared passion which unites and creates a harmonious image of the patriarchal family in its "militant" version that now lives together with the brothers (and sometimes even the sister) reconstituting a unity which had been shattered.

\section{The civil war in Syria and the reserve army of Jihadists in Europe}

Jihadism is one illustration of the globalisation of the phenomena of war. Now the civil war in Syria has its counterpart in France: Daesh transposes this war elsewhere, to Russia (the explosion of the Russian plane in full flight at Sharm elSheikh on 31 October 2015, killing 224 passengers), to Lebanon (explosions on 12 November 2015 killing at least 43 people), Tunisia (18 March, 19 people were shot and killed, mainly foreign tourists, 26 June, 38 people were killed, mainly British tourists) and the list is not exhaustive. This civil war has spinoffs in France as a result of the involvement of French aviation in Syria. Daesh has allowed a few of its adepts to join the refugees fleeing the repression of the Syrian army and the radical Islamists. One of these seems to have implemented his plan of attack in Paris (using a Syrian passport, the bearer of which went through Greece). The new Islamic state is conducting "a total war" all over the world, with innocent people paying for acts of war carried out by national governments. Henceforth Islamist radicals appear to consider the distinction between civilians and combatants outdated; they dehumanize their victims and put them to death in the name of a faith which is firmly rooted in their minds.

The deprived suburbs have become the reserve army of Jihadism: up to January 2015, almost all the French Islamist terrorists who succeeded in implementing their attacks came from deprived suburbs. The public housing estates have become places where an activist minority no longer identifies with any citizenship agenda and go as far as waging the Holy War against society as a whole. Daesh and Al Qaïda draw on this reserve army, the cultural foundation of their adherence to ideologies of hate being their resentment with society which to them 
personifies the ultimate cause of their malaise. People who have broken with social life, destroyed by racism and prejudices express their willingness to fight, kill and die, taking their revenge on society at the expense of killing hundreds, if not thousands, of innocents. Islam becomes the principle of sanctification of their hatred and anything which promotes this desire for vengeance takes on a religious meaning. The Jihad, in this conception, is a war without mercy and without end against the world which has rejected them and which is now "ungodly" if not "heathen". It is quite legitimate, even worthy of praise, to use excessive violence against it. God is personified in a posture of blind violence in a morbid religiosity which totally dehumanizes the opponent. This includes all those who do not think like the fanatic and who only consider this excessive violence to be sacred in meaning.

The middle classes also contribute to this Jihadi reserve army. The 13 November 2015 attacks revealed the involvement of young middle class people, in particular Sami Amimour who had worked for the RATP as a bus driver, or Salah Abdeslam, who had in turn been a technician at the tram terminal and the manager of a bar.

While in France, almost all the perpetrators of the successful Jihadi attacks up to January 2015 have been young people from the deprived suburbs. In the UK, from the beginning the scene has been more complex (in the July 2005 attack on the underground and the bus in London, of the four main protagonists, the leader, Siddique Khan, 30 years old, worked in a primary school. Shehzad Taneer, 22 years, worked in a fish and chip shop). None of the four had any known past of delinquency. As from November 2015, the intervention of the middle classes in Jihadi attacks became much more frequent, even in France (at least three of the eight Jihadi protagonists were of middle class origin).

\section{Conclusion}

The strong solidarities of the welfare state, including working-class solidarity, have declined and nothing has taken their place in a society where narcissistic individualism has become the rule. Both amongst working classes and middle classes, there is a loss of hope in the future and loss of expectations. The lack of reference points is a source of confusion for young people, who have little identification with noble ideals and utopias. The West seems unable to end repression and humanitarian crisis in Syria. Finally young people in deprived areas are powerless and desperate. These are all social facts, which promote Jihadism. Addressing them will not end extremist Islam, but will considerably reduce its attraction. 


\section{References}

Akbarzadeh, Shahram: Islam and Political Violence: Muslim Diaspora and Radicalism in the West. London / New York 2010.

Atran, Scott: "ISIS is a Revolution", in: AEON, 15 December 2015, available at: https://aeon.co/essays/why-isis-has-the-potential-to-be-a-world-altering-revolution [12.04.216].

Bouzar, Dounia: Ils cherchent le paradis, ils ont trouvé l'enfer. Ivry-sur-Seine 2014.

Darmency, Delphine / Desloire, Constance: "Les femmes peshmergas, héroïnes trompeuses de la société kurde", in: Le Monde, 9 octobre 2014.

Halicek, Sasha / Pandith, Farah: "Comment nos filles deviennent des 'califettes"”, in: Le Monde, 28 janvier 2015.

Horgan, John: Psychology of Terrorism. London 2005.

Hoyle, Carolyn / Bradford, Alexandra / Frenett, Ross: Becoming Mulan? Female Western Migrants to ISIS, London 2015.

Khosrokhavar, Farhad: "Le jihadisme féminin en Europe aujourd'hui”, in: Télos, 17 mars 2015a, available at: http://www.telos-eu.com/fr/le-jihadisme-feminin-en-europe-au jourdhui.html [12.04.2016].

Khosrokhavar, Farhad: "Qui sont les jihadistes”, in: Sciences Humaines (268) 2015b, pp. 8-13.

Khosrokhavar, Farhad: Radicalisation. Paris 2014.

Lohlker, Rüdiger (ed.): Jihadism: Online Discourses and Representations. Göttingen 2013.

Lohlker, Rüdiger (ed.): New Approaches to the Analysis of Jihadism. Online and Offline. Göttingen 2012.

McVeigh, Karen: "Peer pressure lures more Britons to Syria than Isis videos, study finds", in: The Guardian, 6 November 2014.

Neumann, Peter R.: Die Neuen Dschihadisten, IS, Europa und die nächste Welle des Terrorismus. Berlin 2015.

Olidort, Jacob: "What Is Salafism? How a Nonpolitical Ideology Became a Political Force", in: Foreign Affairs, 24 November 2015, available at: https://www.foreign affairs.com/articles/syria/2015-11-24/what-salafism [12.04.2016].

Post, Jerrold M.: The Mind of the Terrorist. The Psychology of Terrorism from the IRA to Al-Qaeda. New York 2007.

Raflik, Jenny: Terrorisme et mondialisation. Paris 2016.

Rey-Lefebvre, Isabelle / Piel, Simon / Bastuck, Nicolas / Aubenas, Florence: "Hasna Aït Boulahcen, entre vodka et niqab", in: Le Monde, 21 novembre 2015, available at: http://www.lemonde.fr/attaques-a-paris/article/2015/11/21/hasna-ait-boulahcen-entrevodka-et-niqab_4814800_4809495.html [12.04.2016].

Siddique, Haoon: "Jihadi recruitment video for Islamist terror group Isis features three Britons", in: The Guardian, 20 June 2014.

Salih, Mohammed A.: "Meet the Badass Women Fighting the Islamic State", in: Foreign Policy, 9 December 2014.

Thomson, David: Les Français Jihadistes. Paris 2014. 
Vlierden, Guy van: Profile: Paris Attack Ringleader Abdelhamid Abaaoud, in: CTC Sentinel, 15 December 2015, available at: https://www.ctc.usma.edu/posts/profileparis-attack-ringleader [12.04.2016].

Wievorka, Michel: Sociétés et terrorisme. Paris 1988.

"UK female jihadists run ISIS sex-slave brothels", in: Al Arabia News, 12 September 2014.

"Une adolescente de 14 ans partie en Syrie", in: Le Figaro, 19 juin 2014. 